\title{
PENGARUH HAND MASSAGE TERHADAP PENURUNAN TINGKAT KECEMASAN KLIEN PRE OPERASI DI RUMAH SAKIT PATAR ASIH LUBUK PAKAM TAHUN 2021
}

\section{DIAN ANGGRI YANTI ${ }^{1}$, PITRIANI ${ }^{2}$, LENI SUMIATI SILABAN ${ }^{3}$, SCOLASTIKA PURBA ${ }^{4}$, JUNI MARIATI SIMARMATA ${ }^{5}$}

\author{
1,2,3,4,5 Institut Kesehatan Medistra Lubuk Pakam \\ Jl. Sudirman No.38 Lubuk Pakam Kab. Deli Serdang \\ e-mail: diananggriyanti87@gmail.com
}

DOI $10.35451 /$ jkf.v3i2.606

\begin{abstract}
The number of patients with surgery has increased significantly from year to year. Recorded in 2011 there were 140 million patients in all hospitals in the world, Anxiety is a common thing in patients who are going to undergo surgery. Anxiety that occurs with preoperative patients can be felt since the start of being scheduled for surgery until the time for surgery arrives and hand massage can be useful to reduce pain because it has a relaxing effect and reduces anxiety. Purpose: to determine the effect of hand massage on the reduction of preoperative client anxiety levels at Patar Asih Lubuk Pakam Hospital in 2021. Method: Pre-experimental design with one-group pre-post test design. The research subjects were preoperative inpatients. Population: preoperative patients in Galilee inpatient room. Sample: purposive sampling. Results: After the hand massage treatment, the level of anxiety in the treatment group decreased significantly, while the control group did not experience a significant decrease. In the control group the pre-test average was 19.63, while the post-test average was 19.06, this indicates a very small decrease so that the decrease was not significant. In the treatment group the average before treatment was 19.94 after treatment decreased to 16.19. Conclusion: The results of hypothesis testing $(p<0.05)$ prove that hand massage significantly reduces anxiety levels before surgery.
\end{abstract}

Keywords: Patients with preoperative, hand massage treatment, level of anxiety.

\section{PENDAHULUAN}

Operasi atau yang biasa dikenal masyarakat adalah pembedahan merupakan salah satu penanganan medis invasive untuk mengobati penyakit, injury, atau deformitas anggota tubuh, tindakan operasi atau pembedahan akan menciderai jaringan tubuh yang dapat mengakibatkan perubahan fisiologis tubuh sehingga mempengaruhi pada organ-organ tubuh lainnya (Rismawan, 2019).
Pra-operasi merupakan suatu tahap awal yang harus dilaksanakan dari fase perioperatif. Fase ini dimulai saat seseorang yang disebut klien diputuskan oleh pihak medis harus menjalani operasi atau pembedahan dan dianjurkan melakukan persiapan pra-operasi hingga seorang klien tersebut tiba di meja pembedahan (Kozier, 2010). Peran seorang perawat di tahap awal pra-operasi dalam hal ini yaitu terlebih dahulu melakukan pengkajian keadaan atau status 
kesehatan fisiologis dan psikologis klien. Pengkajian yang dilakukan tersebut bertujuan untuk memenuhi kebutuhan-kebutuhan klien yang berhubungan dengan persiapan dalam menghadapi pembedahan sebagai upaya untuk mendukung kesuksesan tindakan operasi atau pembedahan (Sitompul, 2017).

Prosedur tindakan operasi merupakan suatu terapi dalam dunia medis yang kemungkinan dapat menimbulkan perasaan takut, cemas hingga stres, karena dianggap dapat mengancam integritas tubuh, jiwa dan dapat menimbulkan rasa nyeri. Peran perawat sangat penting dalam keberhasilan setiap tindakan operasi atau pembedahan, yaitu salah satunya untuk membantu pasien memahami tentang tindakan-tindakan yang akan dilakukan dengan cara memberikan informasi yang benar agar dapat mengurangi bahkan menghilangkan rasa cemas yang dialami oleh klien (Rismawan, 2019).

World Health Organization (WHO), menyatakan jumlah klien yang menjalani tindakan operasi mencapai angka peningkatan yang sangat signifikan setiap tahunnya. Tercatat di tahun 2011 ada 140 juta jiwa klien di semua rumah sakit di dunia, tahun 2012 mengalami peningkatan jumlah menjadi 148 juta jiwa. Tindakan operasi/pembedahan di Indonesia tahun 2012 mencapai hingga 1,2 juta jiwa. Data Tabulasi Nasional Departemen Kesehatan Republik Indonesia pada tahun 2017, tindakan operasi/pembedahan menempati urutan posisi ke-11 dari 50 pertama dalam penanganan penyakit yang ada di rumah sakit seluruh Indonesia diperkirakan sekitar 32\% diantaranya yaitu merupakan tindakan pembedahan laparatomi (Hartoyo, 2015) dalam penelitian (Rismawan, 2019).

Caumo, dkk (2001) dalam penelitian (Sitompul, 2017) membuktikan 11-80 \% klien dengan usia dewasa mengalami suatu kecemasan pada tahap pra-operasi. Hal ini menjelaskan bahwasannya hampir semua klien dewasa yang akan menjalani tindakan operasi mengalami kecemasan, dengan alasan mereka khawatir akan tindakan pembiusan dan proses pembedahan yang akan dijalani.

Kecemasan merupakan suatu hal yang biasanya terjadi pada klien yang menjalani prosedur tindakan pembedahan. Kecemasan yang terjadi pada klien tersebut pada tahap praoperasi dapat dirasakan sejak mulai diputuskan, kemudian dijadwalkan hingga waktu prosedur tindakan operasi akan dilakukan (Poororajal, Ashtarani, and Alimohammadi, 2017) dalam penelitian (Pefbrianti, 2018).

Pritchard (2011) menyatakan bahwa klien dengan rencana tindakan pembedahan mengatakan takut dan cemas karena menganggap setelah menjalani tindakan pembedahan tersebut akan sulit melakukan aktivitas sehari-hari, mengalami nyeri, terjadinya perubahan pada bentuk tubuh, risiko terjadinya infeksi hingga mengakibatkan kematian. Hal tersebut didukung oleh penelitian Devi (2002) yaitu dalam mengukur adanya tingkat kecemasan klien yang menjalani suatu tindakan operasi, dari 30 orang jumlah sampel diperoleh gambaran $15.8 \%$ klien mengalami kecemasan ringan dan sebagian besar mengalami kecemasan sedang $(84,2 \%)$ hal tersebut ditandai dengan mukosa mulut dan bibir kering, terjadi anoreksia, gemetar, sering buang air kecil, menunjukkan ekspresi wajah gelisah, tidak rileks, sulit tidur, meremas-remas tangan, banyak berbicara, dan volume suara keras (Sitompul, 2017).

Dampak kecemasan pada respons fisiologis yaitu abnormalnya hemodinamik seperti terjadinya hipertensi dan takikardi (Grieve, 2011) dalam penelitian (Sitompul, 2017). Angka kejadian kecemasan pada klien pra-operasi di Amerika mencapai 28\% atau lebih. Tingkat usia yang biasanya mengalami kecemasan adalah 9-17 tahun sebanyak $13 \%$, usia 18-54 tahun $16 \%$, usia 55 dan lasia sebanyak $11,4 \%$. Sedangkan untuk jenis kelamin wanita 2 kali lebih banyak berisiko mengalami kecemasan dibandingkan yang berjenis kelamin laki-laki (Fortinesh, 2007) dalam penelitian (Vellyana, 2017). 
Gangguan kecemasan atau yang dikenal dengan ansietas merupakan suatu kelompok gangguan psikiatri yang paling sering ditemukan. National Comordibity Study melaporkan bahwa 1 dari 4 orang pasien memenuhi kriteria yaitu mengalami cemas dan angka prevalensi selama 12 bulan sebesar $17,7 \%$. Indonesia sendiri telah dilakukan survey untuk mengetahui prevalensi kejadian gangguan mental emosional seseorang di Indonesia seperti tingkat kecemasan dan depresi sebesar $11,6 \%$ pada usia $>15$ tahun (Furwanti dkk, 2014) dalam penelitian (Rismawan, 2019).

Penanganan kecemasan, yang bersifat non farmakologi dapat dipercaya berperan dalam mengatasi rasa cemas seperti teknik napas dalam, terapi musik klasik, massage, dan juga terapi wewangian (aromaterapi). Hand massage dikenal dengan tindakan pemijatan pada tangan dengan tehnik lima langkah pemijatan menggunakan minyak. Kim dkk (2013) telah membuktikan pada klien yang menjalani pembedahan katarak bahwa terapi pemijatan dapat menurunkan tingkat kecemasan seorang klien secara fisik dan psikologis. Tindakan Massage dapat merangsang peningkatan hormon oksitosin dan mengurangi hormon adrenocortiko trofin (ACTH) pada manusia (Sitompul, 2017).

Upaya yang dilakukan dalam penanganan dalam masalah kecemasan pada fase pra-operasi yang dilakukan oleh dokter ahli anestesi yaitu memberikan terapi medikasi bersama perawat terkait pendidikan/penyuluhan kesehatan tentang tehnik latihan napas dalam dan pemberian informasiinformasi prosedur operasi/ pembedahan yang akan dilakukan. Belum ada upaya penanganan masalah kecemasan dengan menerapkan terapi pemijatan pada tangan atau hand massage oleh perawat (Sitompul, 2017).

Hand massage dikenal dengan pijat sederhana yang memberikan rasa nyaman, pemijatan dilakukan dengan santai khususnya bagi yang mengalami stres, mengalami kesulitan dalam membina hubungan dengan orang lain, hand massage ini juga dapat berguna untuk mengurangi atau menghilangkan rasa sakit karena menimbulkan efek relaksasi dan dapat mengurangi kecemasan. Hand massage juga dapat diterapkan untuk membantu mengurangi behavioural and psychological symptoms of dementia (BPSD) (Pramesti, 2020).

Hand massage juga menjadi pilihan untuk memberikan sensasi kenyamanan yang dapat meredakan ketegangan akibat nyeri dan membuat klien menjadi rileks. Pengaruh yang ditimbulkan dari terapi hand massage adalah untuk mengurangi ketegangan, dapat meningkatkan relaksasi fisik klien dan juga psikologinya. Hand massage ini juga dapat membantu dalam hal kemandirian klien bersama keluarganya dalam upaya mengelola nyeri yang dirasakan, khususnya bagi klien yang tidak bersedia mengatasi nyerinya dengan menjalani terapi farmakologi. Selain itu dalam pemberian terapi hand massage tidak memerlukan peralatan khusus yang membutuhkan biaya besar sehingga terapi ini dapat diterapkan pada klien dengan strata ekonomi apapun (Fadilah, 2016).

\section{METODE}

Penelitian menggunakan rancangan Pra-eksperimental dengan penelitian one-group pre-post test design. Ciri dari penelitian ini adalah untuk mengungkap adanya hubungan sebab akibat dengan cara melibatkan satu kelompok subjek. Kelompok subjek tersebut diobservasi sebelum diberikan intervensi, kemudian dilakukan observasi kembali setelah diberikan intervensi (Nursalam, 2014). Peneliti akan memberikan tindakan Hand Massage untuk menurunkan tingkat kecemasan klien pada tahap pra operasi.

Dalam penelitian ini yang akan Penelitian ini meneliti pengaruh Hand Massage pada tingkat kecemasan klien pre operasi, dimana diberikan perlakuan tertentu dilakukan observasi pada saat pre-test, kemudian setelah perlakuan, dilakukan lagi untuk 
mengetahui sebab-akibat dari perlakuan. Pengujian sebab-akibat dilakukan dengan cara membandingkan hasil pre-test dan post-test (Nursalam, 2014).

Analisa data yang digunakan adalah Univariat dan Bivariat. Analisa Univariat untuk menjelaskan atau mendiskripsikan rata-rata tingkat cemas seseorang sebelum dilakukan terapi hand massage dan rata-rata tingkat kecemasan seseorang sesudah dilakukan terapi hand massage pada pasien yang akan menjalani tindakan operasi/pembeedahan.

Analisa Bivariat diperlukan untuk menjelaskan atau mengetahui apakah ada pengaruh atau tidak antara variabel dependent dan variabel independent. Data dianalisis untuk perhitungan bivariat pada penelitian ini menggunakan uji statistic Paired Sample T-Test dengan taraf tingkat kepercayaan $\quad 95 \% \quad$ (pValue $\leq a)$. Pembuktian ini dilakukan untuk membuktikan hipotesis adakah apabila nilai $p \leq 0,05$.

\section{HASIL}

\section{Analisa Univariat} Karakteristik Responden dalam
penelitian ini berdasarkan umur dan jenis pendidikan adalah sebagai berikut:

Tabel 3.1 Distribusi Frekuensi Berdasarkan Karakteristik Responden di Rumah Sakit Patar Asih Lubuk Pakam Tahun 2021

\begin{tabular}{|c|c|c|}
\hline \multirow{2}{*}{$\begin{array}{l}\text { Karakteris } \\
\text { tik }\end{array}$} & Kel. Kontrol & $\begin{array}{l}\text { Kel. } \\
\text { Perlakuan }\end{array}$ \\
\hline & $\%$ & $\%$ \\
\hline
\end{tabular}

\begin{tabular}{|c|c|c|c|c|}
\hline \\
\hline$<21$ thn & 0 & 0 & 2 & 12,5 \\
\hline $21-25$ thn & 7 & 43,8 & 7 & 43,8 \\
\hline $26-30$ thn & 7 & 43,8 & 5 & 31,3 \\
\hline$>31$ thn & 2 & 12,5 & 2 & 12,5 \\
\hline \multicolumn{5}{|l|}{ Pendidikan } \\
\hline SMP & 6 & 37,5 & 6 & 37,5 \\
\hline SMA & 7 & 43,8 & 8 & 50,0 \\
\hline DIII/S1 & 3 & 18,8 & 2 & 12,5 \\
\hline \multicolumn{3}{|c|}{ Karakteristik } & \multicolumn{2}{|c|}{ responden } \\
\hline $\begin{array}{l}\text { berdasarka } \\
\text { menuniukk }\end{array}$ & & $\begin{array}{l}\text { pad } \\
\text { jian }\end{array}$ & $\begin{array}{l}\text { tab } \\
\text { esa }\end{array}$ & $\begin{array}{l}3.1 \\
\text { dari }\end{array}$ \\
\hline
\end{tabular}

responden pada kelompok kontrol terdapat usia 21-25 tahun (43,8 \%) sedangkan responden pada kelompok perlakuan sebagian besar juga berusia 21-25 tahun (43,8 \%). Tingkat pendidikan responden pada tabel 4.1 menunjukkan pada kelompok kontrol sebagian besar menunjukkan pendidikan SMA sebanyak 7 orang $(43,8 \%)$ dan pada kelompok perlakuan sebagian besar juga berpendidikan SMA yaitu 8 orang (50\%).

Tingkat kecemasan klien pre operasi sebelum dilakukan hand massage di Rumah Sakit Patar Asih Lubuk Pakam Tahun 2021

Hasil penelitian terhadap 20 orang responden berdasarkan tingkat kecemasan klien sebelum dilakukan hand massage dapat dilihat pada tabel 3.2 dibawah ini, yakni:

Tabel 3.2 Distribusi Frekuensi

Tingkat Kecemasan Klien Pre Operasi Sebelum Dilakukan (pre test) Hand Massage di Rumah Sakit Patar Asih Lubuk Pakam Tahun 2021

\begin{tabular}{|c|c|c|c|c|c|}
\hline \multirow{2}{*}{$\begin{array}{l}\text { Skala } \\
\text { Cemas }\end{array}$} & \multirow{2}{*}{$\begin{array}{c}\text { Ting } \\
\text { kat } \\
\text { Kece } \\
\text { mas } \\
\text { an }\end{array}$} & \multicolumn{2}{|c|}{$\begin{array}{l}\text { Kelom } \\
\text { pok } \\
\text { Kontrol }\end{array}$} & \multicolumn{2}{|c|}{$\begin{array}{l}\text { Kelompok } \\
\text { Perlakuan }\end{array}$} \\
\hline & & f & $\%$ & $f$ & $\%$ \\
\hline & $\begin{array}{l}\text { Kecem } \\
\text { asan } \\
\text { ringan }\end{array}$ & 10 & 62,5 & 9 & 56,3 \\
\hline & $\begin{array}{c}\text { Kecem } \\
\text { asan } \\
\text { sedan } \\
\mathrm{g}\end{array}$ & 6 & 37,8 & 7 & 43,8 \\
\hline Total & & 16 & 100 & 16 & 100 \\
\hline
\end{tabular}

Berdasarkan tabel 3.2 menunjukkan sebelum diberikan perlakuan sebagian besar dari responden mengalami tingkat kecemasan ringan, yaitu sebanyak 10 orang responden $(62,5 \%)$ pada kelompok kontrol, dan sebanyak 9 orang responden $(56,3 \%)$ pada kelompok perlakuan.

Tingkat kecemasan klien pre operasi sesudah dilakukan hand massage di Rumah Sakit Patar Asih Lubuk Pakam Tahun 2021 
Hasil penelitian terhadap 20 orang responden berdasarkan tingkat kecemasan klien sebelum dilakukan hand massage dapat dilihat pada tabel 3.3 dibawah ini, yakni:

\begin{tabular}{|c|c|c|c|}
\hline \multirow{2}{*}{$\begin{array}{l}\text { Skal } \\
\text { a } \\
\text { Cem } \\
\text { as }\end{array}$} & \multirow{2}{*}{$\begin{array}{l}\text { Tingk } \\
\text { at } \\
\text { Kece } \\
\text { masa } \\
\text { n }\end{array}$} & $\begin{array}{l}\text { Kelompok } \\
\text { Kontrol }\end{array}$ & $\begin{array}{l}\text { Kelompok } \\
\text { Perlakuan }\end{array}$ \\
\hline & & f $\%$ & f $\quad \%$ \\
\hline & $\begin{array}{l}\text { Tidak } \\
\text { ada } \\
\text { Kecem } \\
\text { asan }\end{array}$ & 6,3 & 25,0 \\
\hline
\end{tabular}

$\begin{array}{lllll}\begin{array}{l}\text { Kecem } \\ \text { asan }\end{array} & 10 & 62,5 & 11 & 68,8 \\ \text { ringan } & & & & \\ \end{array}$

\begin{tabular}{ccccc}
$\begin{array}{l}\text { Kecem } \\
\text { asan } \\
\text { sedan } \\
\text { g }\end{array}$ & 5 & 31,3 & 1 & 6,3 \\
\hline Total & 16 & 100 & 16 & 100 \\
\hline Berdasarkan & tabel & 3.3
\end{tabular}

menunjukkan sesudah diberi perlakuan pada responden dalam kelompok kontrol terdapat 1 orang responden $(6,3 \%)$ tidak mengalami cemas, sebanyak 10 orang responden $(62,5 \%)$ mengalami cemas ringan, dan 5 pasien $(31,3 \%)$ mengalami cemas sedang dan tidak ada responden yang mengalami cemas berat. Pada kelompok perlakuan 4 orang responden $(25,0 \%)$ tidak mengalami cemas, 11 orang responden $(68,8 \%)$ mengalami kecemasan ringan, 1 orang responden $(6,3 \%)$ dengan kecemasan sedang dan tidak ada yang mengalami kecemasan berat.

\section{Analisa Bivariat}

Analisa bivariat digunakan untuk mengetahui adanya pengaruh hand massage terhadap penurunan tingkat kecemasan pada pasien pra operasi. Analisa data terdiri dari beda independent t-test dan uji pairedsample $t$ test, adapun hasilnya sebagai berikut:

Uji independent sample $t$ test pada penelitian ini digunakan untuk mengetahui adanya perbedaan tingkat kecemasan pada kelompok kontrol dan kelompok perlakuan, adapun hasil ujinya sebagai berikut:

Tabel 3.4 Hasil Uji Independent Sample $t$ test

\begin{tabular}{|c|c|c|c|c|}
\hline \multirow[b]{2}{*}{ Kelompok } & \multicolumn{2}{|c|}{ Pre Test } & \multicolumn{2}{|c|}{ Post Test } \\
\hline & $\begin{array}{l}\mathrm{T} \\
\text { hitung }\end{array}$ & $p$ & $\begin{array}{l}\mathrm{T} \\
\text { hitung }\end{array}$ & $p$ \\
\hline Kontrol & 0,235 & 0,815 & 2,293 & 0,029 \\
\hline Perlakuan & & & & \\
\hline
\end{tabular}

Hasil uji independent sample $t$ test kecemasan pra test antara kelompok perlakuan dengan kelompok kontrol diperoleh nilai sebesar 0,235 sedangkan sebesar 2,042, karena $(0,235)<(2,0,42)$ maka Ho diterima dan $\mathrm{Ha}$ ditolak, artinya tidak ada perbedaan tingkat kecemasan pasien pada kelompok perlakuan dan kelompok kontrol sebelum diberikan perlakuan. Hasil tersebut menunjukkan kondisi awal sebelum perlakuan pada kedua kelompok dengan tingkat kecemasan yang sama artinya kedua kelompok sebelum perlakuan dengan kondisi awal setara atau asas kesetaraan terpenuhi.

Hasil independent sample $t$ test tingkat kecemasan post test antara kelompok perlakuan dengan kelompok kontrol diperoleh nilai sebesar 2,293, sedangkan sebesar 2,042 , karena $(2,293)>(2,042)$ maka Ho ditolak dan Ha diterima, artinya ada perbedaan tingkat kecemasan pada kelompok perlakuan dan kelompok kontrol sesudah diberikan perlakuan.

Uji paired-sample $t$ test digunakan untuk mengetahui adanya perbedaan tingkat kecemasan sebelum dan sesudah diberikan perlakuan, adapun hasil uji sebagai berikut:

Tabel 3.5 Hasil Uji Paired T Test

\begin{tabular}{lllll}
\hline & \multicolumn{2}{l}{ Kontrol } & \multicolumn{2}{l}{ Perlakuan } \\
\cline { 2 - 5 } & thitun & $p$ & thit & ung \\
& $\mathrm{g}$ & $p$ & \\
-value \\
\hline Pre & 2,058 & 0, & 9,3 & 0,001 \\
Test & & 0 & 03 & \\
Post & & 5 & & \\
Test & & 7 & & \\
\hline
\end{tabular}

Hasil uji paired-sample $t$ test kecemasan pre test dan post test kelompok kontrol diperoleh nilai sebesar 2,058, sedangkan sebesar 2,131 , karena $(2,058)<(2,131)$ maka 
Ho diterima dan Ha ditolak, artinya tidak ada perbedaan tingkat kecemasan pasien sebelum dan sesudah pada kelompok kontrol.

Hasil uji paired-sample $t$ test kecemasan pre test dan post test kelompok perlakuan diperoleh nilai sebesar 9,303, sedangkan sebesar 2,131 , karena $(9,303)>(2,131)$ maka Ho ditolak dan Ha diterima, artinya ada perbedaan tingkat kecemasan pasien sebelum dan sesudah diberikan perlakuan.

\section{PEMBAHASAN}

\subsection{Tingkat Kecemasan Sebelum Hand Massage}

Hasil penelitian menunjukkan baik kelompok perlakuan maupun kelompok kontrol dengan tingkat kecemasan yang sama, yaitu rata-rata mengalami tingkat kecemasan ringan, yaitu sebanyak 10 pasien $(62,5 \%)$ pada kelompok kontrol dan sebanyak 9 pasien $(56,3 \%)$ pada kelompok perlakuan. Hal tersebut berkaitan dengan penelitian yang dilakukan oleh (Mulyani, 2013) yang mengemukakan bahwa sebagian besar pasien yang akan dilakukan pembedahan mengalami kecemasan ringan yaitu $52,5 \%$ dan $47,5 \%$ mengalami kecemasan sedang.

Munculnya kecemasan menjelang operasi adalah hal yang wajar. Hal ini sesuai dengan penjelasan Potter dan Perry (2006) bahwa respon psikologi yang biasanya terjadi pada pasien pre operasi yaitu kecemasan. Tindakan operasi berpotensi menimbulkan akan memikirkan kondisi dirinya sendiri, mereka akan memikirkan tentang kondisi selama diruang operasi sehingga hal ini dapat mempengaruhi kecemasan pada pasien pre operasi (Sriningsih dan Afriani, 2014). Kecemasan yang terjadi pada klien dihubungkan dengan rasa nyeri, kemungkinan mengalami kecacatan, menjadi bergantung hidup pada orang lain bahkan mungkin terjadi kematian. Tindakan operasi atau pembedahan merupakan suatu pengalaman sulit bagi semua klien, dianggap adanya kemungkinan buruk yang bisa terjadi sehingga menimbulkan bahaya bagi klien yang menjalaninya. Oleh karena itu, seringkali klien menunjukkan sikap yang berlebihan akibat tingkat kecemasan yang mereka alami (Faradisi, 2012).

Tingkat kecemasan seseorang dalam menghadapi permasalahan yang sama, tetapi nilai kecemasan tersebut memiliki beberapa tingkatan atau level yaitu cemas ringan, cemas sedang, cemas berat dan panik (Stuart, 2007). Kecemasan merupakan perasaan yang paling umum yang biasanya dialami oleh seseorang, dimana kecemasan menunjukkan reaksi terhadap bahaya yang mengingatkan seseorang dari dalam secara naluri, bahwa akan menimbulkan bahaya dan orang yang bersangkutan mungkin dapat kehilangan kendali dalam menghadapi situasi tersebut (Carpenito, 2006).

Faktor - faktor yang mempengaruhi ketika seorang klien akan menjalani tindakan operasi diantaranya adalah tingkat pengetahuan, dukungan keluarga, faktor ekonomi dan faktor psikologis. Pengalaman atau pengetahuan berhubungan dengan perilaku yang didasari oleh pengetahuan dimana seseorang akan mengalami kecemasan dengan tidak mengetahui tentang operasi dan bagaimana prosesnya. Kecemasan dapat terjadi pada seseorang dengan pengetahuan rendah tentang proses operasi yang disebabkan karena kurangnya informasi yang diperoleh (Notoatmodjo, 2010).

\section{Tingkat Kecemasan Sesudah Hand Massage}

Hasil penelitian menunjukkan bahwa sesudah diberi perlakuan pada kelompok perlakuan 4 orang responden $(25,0 \%)$ tidak mengalami cemas, 11 orang responden $(68,8 \%)$ mengalami cemas ringan, 1 orang responden $(6,3 \%)$ dengan cemas sedang dan tidak ada yang mengalami cemas berat. Pada kelompok kontrol 1 orang responden $(6,3 \%)$ tidak cemas, 10 orang responden $(62,5 \%)$ dengan cemas ringan, 5 orang responden $(31,3 \%)$ dengan cemas sedang dan 
Received: 31 Maret 2021 :: Accepted: 29 April 2021 :: Published: 30 April 2021

tidak ada yang mengalami cemas berat.

Hasil penelitian menggambarkan pada kelompok kontrol tingkat kecemasan masih tetap, rata-rata cemas cenderung sedang atau meningkat. Sedangkan pada kelompok perlakuan yang diberikan teknik relaksasi hand massage tingkat kecemasan cenderung turun ke cemas ringan dan berpotensi tidak cemas. Hal ini memberikan informasi bahwa pada kelompok perlakuan yang diberikan tindakan hand massage mampu memberikan efek yaitu menurunkan tingkat kecemasan.

Liana (2008) dalam Pinandita et al. (2012), pijat pada tangan disertai dengan melakukan tehnik menarik nafas dalam dapat mengurangi/ menghilangkan ketegangan fisik dan emosi, karena pijat pada tangan dapat menghangatkan area titik masuk dan keluar energi yang ada pada meridian (saluran energy) yang berhubungan dengan organ-organ di dalam tubuh manusia yang terletak pada jari tangan manusia. Titik-titik refleksi yang terdapat pada tangan dapat menimbulkan rangsangan secara refleks (spontan) pada saat melakukan genggaman. Rangsangan yang diberikan tersebut akan mengalirkan semacam bentuk gelombang kejut atau listrik menuju otak kemudian diproses dengan cepat kemudian diteruskan menuju syaraf-syaraf pada organ tubuh manusia yang mengalami gangguan, sehingga adanya sumbatan di jalur energi akan hilang dan alirannya menjadi lancar. Relaksasi pemijatan pada tangan dapat membantu mengendalikan emosi yang akan membuat tubuh seseorang menjadi rileks. Ketika tubuh dalam keadaan rileks, maka ketegangan pada otot berkurang yang kemudian akan mengurangi kecemasan (Yuliastuti, 2015).

Stuart (2007) menyatakan bahwa teknik hand massage dapat membantu tubuh, pikiran dan jiwa untuk mencapai tingkat relaksasi. Teknik hand massage juga merupakan suatu tindakan yang dapat diterapkan untuk membebaskan mental dan fisik dari ketegangan dan stres, sehingga dapat meningkatkan toleransi terhadap skala nyeri. Hal tersebut juga sesuai dengan penjelasan Ali dan Hasan (2010) yang mengemukakan bahwa hand massage adalah metode pengobatan yang efektif dalam mengurangi depresi dan gangguan mental berupa kecemasan. Salah satu teknik relaksasi yang dapat digunakan untuk menurunkan kecemasan adalah teknik relaksasi dan pijat tangan. Teknik hand massage merupakan cara yang sangat mudah untuk mengendalikan emosi. Emosi adalah seperti gelombang energi yang berpindah melalui anggota tubuh, pikiran dan jiwa seseorang.

\section{Pengaruh Hand Massage Terhadap Penurunan Tingkat Kecemasan pada Pasien Pre Operasi}

Setelah adanya perlakuan hand massage tingkatan kecemasan pada kelompok perlakuan mengalami penurunan yang signifikan, sedangkan tingkat kecemasan pada kelompok kontrol tidak mengalami penurunan yang signifikan. Pada kelompok kontrol rata-rata pre test sebesar 19,63 sedangkan post test sebesar 19,06 hal ini menunjukkan adanya penurunan yang sangat kecil sehingga penurunannya tidak signifikan. Pada kelompok perlakuan rata-rata sebelum perlakuan sebesar 19,94 setelah perlakuan turun menjadi 16,19 . Hasil pengujian hipotesis $(p<0,05)$ membuktikan hand massage signifikan menurunkan tingkat kecemasan menjelang operasi.

Penurunan tingkat kecemasan pada pasien pre operasi disebabkan karena hand massage. Hand massage yang dilakukan akan memberikan rasa hangat pada titik-titik keluar dan masuknya energi pada meridian (saluran energi) yang berhubungan dengan system organ di dalam tubuh serta emosi yang berkaitan yang terletak di jari tangan seseorang (Liana, 2008 dalam Pinandita et al, 2012). Setiap jari tangan seseorang berkaitan erat dengan sikapnya sehari hari. Ibu jari berkaitan dengan rasa khawatir, rasa takut dikaitkan dengan jari telunjuk, jari tengah dikaitkan 
dengan kemarahan, jari manis dengan kesedihan sedangkan jari kelingking dikaitkan dengan perasaan rendah diri dan kecil hati (Hill, 2011).

Titik-titik refleksi pada tangan seseorang memberikan rangsangan secara refleks pada saat melakukan genggaman. Rangsangan tersebut akan mengalirkan semacam bentuk gelombang kejut / listrik menuju otak kemudian diproses secara cepat kemudian diteruskan menuju sarafsaraf pada organ tubuh seseorang yang mengalami gangguan, sehingga sumbatan-sumbatan di jalur energi menjadi lancar (Liana, 2008 dalam Pinandita et al, 2012). Sumbatan di jalur energi tersebut merupakan perasaan yang tidak seimbang misalnya khawatir, kecemasan, marah, takut dan kesedihan yang dapat menghambat aliran-aliran energi yang dapat mengakibatkan perasaan tidak nyaman dalam tubuh seseorang (Hill, 2011). Hand massage dapat mengendalikan emosi seseorang sehingga dapat membuat tubuhnya menjadi rileks (Pinandita et al, 2012). Ketika tubuh seseorang dalam kondisi rileks, maka ketegangan pada otot tubuh menjadi berkurang yang kemudian dapat mengurangi tingkat kecemasan seseorang tersebut (Yuliastuti, 2015).

Hasil tersebut didukung penelitiam Ma'rifah et al, (2015) tentang efektifitas hand massage terhadap penurunan skala nyeri pada pasien post operasi section caesarea di RSUD Prof. Dr. Margono Soekardjo Purwokerto, dalam penelitian tersebut didapatkan hasil bahwa teknik hand massage mempunyai nilai efektifitas lebih baik dalam menurunkan nyeri post operasi section caesarea.

\section{KESIMPULAN}

Pada kelompok kontrol sebelum diberikan intervensi (pre test) sebagian besar responden mengalami tingkat cemas ringan dan setelah diberikan intervensi (post test) sebagian besar responden dengan tingkat cemas ringan dan sedang. Pada kelompok perlakuan sebelum diberikan terapi hand massage (pre test), sebagian besar responden dengan tingkat cemas ringan dan sedang sedangkan setelah diberikan terapi hand massage (post test) sebagian besar responden dengan tingkat cemas ringan dan tidak ada kecemasan.

Terdadap perbedaan tingkat kecemasan sebelum dan sesudah dilakukan hand massage terhadap penurunan kecemasan pada pasien pre operasi.

\section{DAFTAR PUSTAKA}

Amilia, A. M. (2019). Hubungan Efikasi Diri Dengan Kecemasan Pada Pasien Pre Operasi Di Rumah Sakit Tingkat Iii Baladhika Husada Jember.

Emilia, L. T., \& Wahyuni, T. (2018). Analisis Praktik Klinik Keperawatan pada Pasien Post Debridement dan Selulitis Pedis dengan Intervensi Inovasi Hand Massage Menggunakan Minyak Essensial Lavender terhadap Penurunan Intensitas Nyeri di Ruang ICU RSUD Abdul Wahab Sjahranie Samarinda Tahun 2018.

Fadilah, P. N., \& Astuti, P. (2016). Pengaruh Teknik Relaksasi Hand Massage Terhadap Nyeri pada Pasien Kanker Payudara di Yayasan Kanker Indonesia Surabaya. Journal of Health Sciences, 9(2).

Notoatmodjo. 2010. Metodologi Penelitian Kesehatan. Yogyakarta: PT Rineka Cipta.

Nursalam. 2008. Konsep dan Penerapan Metodologi Penelitian Keperawatan. Jakarta: Salemba Medika

Nursalam. 2013. Konsep Penerapan Metode Penelitian IImu Keperawatan. Jakarta: Salemba Medika.

Pefbrianti, D., Hariawan, H., Kurniawan, S., Sasongko, H., \& Yusuf, A. (2018). Intervensi Nonfarmakologik Untuk Menurunkan Kecemasan Pada Pasien Preoperasi: Literature Review. Jurnal Penelitian 
Kesehatan" SUARA

FORIKES"(Journal of Health

Research" Forikes Voice"), 9(2), 86-89.

Pinandita (2012). Pengaruh Teknik Relaksasi Genggam Jari Terhadap Penurunan Intensitas Nyeri Pada Pasien Post Operasi Laparatomi. Jurnal Keperawatan. Gombong: Prodi Keperawatan Stikes Muhammadiyah Gombong.

Pramesti Rini, R. A. (2020). Pengaruh Kombinasi Aromaterapi Lavender dan Hand Massage Terhadap Perubahan Kecemasan, Tekanan Darah dan Kortisol pada Pasien Hipertensi. Jurnal Penelitian Kesehatan" SUARA FORIKES"(Journal of Health Research" Forikes Voice"), 11(2), 178-182.

Rismawan, W. (2019). Tingkat Kecemasan pasien ore-operasi di RSUD dr. Soekardjo Kota Tasikmalaya. Jurnal Kesehatan Bakti Tunas Husada: Jurnal Ilmiilmu Keperawatan, Analis Kesehatan dan Farmasi, 19(1).

SARI, R. D. K. (2016). Pengaruh Teknik Relaksasi Genggam Jaru Terhadap Penurunan Kecemasan Pada Pasien Pre Operasi Sectio Caesarea

Sastroasmoro dan Ismail. 2001. Dasardasar Metodologi Penelitian Klinis, Sagung Seto, Jakarta.

Sitompul, E. (2017). Hand Massage Terhadap Penurunan Tingkat Kecemasan Klien Pra-Operasi Pada Pembedahan Elektif. Jurnal Persatuan Perawat Nasional Indonesia (JPPNI), 1(1), 20-26.

Sugiyono. 2011. Metode Penelitian Kuantitatif, Kualitatif dan $R$ \& $D$. Bandung : Alfabeta.

Vellyana, D., Lestari, A., \& Rahmawati, A. (2017). Faktor-faktor yang berhubungan dengan tingkat kecemasan pasa pasien preoperative di RS Mitra Husada Pringsewu. Jurnal Kesehatan, 8(1), 108-113 